\title{
The Redeemed Old Head: Articulating a Sense of Public Self and Social Purpose
}

\author{
Alford A. Young Jr. \\ University of Michigan
}

\begin{abstract}
The notion of the "old head" has emerged as a formidable social type in studies of African American, low-income, urban communities. The term refers to men who have had stable work histories and who reflect "mainstream" values concerning work ethic and social conduct. This analysis broadens the category of old head by exploring the views of men whose life courses have taken different turns than have traditional old heads. Through an analysis of the view of two African American men on their life experiences and efforts to serve as mentors to younger people in their lives, this article delivers an argument about the redeemed old head. This figure is defined in partial contrast to sociological depictions of traditional old heads in that the redeemed old head has led a life of profligate activity as a youth, but now has on his mind the interests and prospects of younger people, some of whom are involved in such profligate activity themselves. Elements of symbolic interactionist theory are employed to make sense of how the redeemed old head conceives of his public self and argues for the limits and possibilities for service as a mentor.
\end{abstract}

It is common for urban ethnographers to depict and illustrate the social dynamics of disadvantaged communities by making reference to social types. Georg Simmel, one of the first sociologists to make use of this concept, discussed social types as robust images of people who hold membership in a particular social category. Social types, therefore, signify definitive positions in the social world (Simmel 1971:141-213). ${ }^{1}$ They are formulated out of the reactions and expectations that others have toward those in that category. The reactions and expectations are produced through social relations, whereby people develop understandings about each other and how others relate to the broader social and physical environment. These social relations are both products and producers of social structures. That is, people interact on the basis of

Direct all correspondence to Alford A. Young Jr., Department of Sociology and Center for Afroamerican and African Studies, University of Michigan, 500 S. State Street, Ann Arbor, MI 48109; e-mail: ayoun@umich.edu.

Symbolic Interaction, Vol. 30, Issue 3, pp. 347-374, ISSN 0195-6086, electronic ISSN 1533-8665. () 2007 by the Society for the Study of Symbolic Interaction. All rights reserved. Please direct all requests for permission to photocopy or reproduce article content through the University of California Press's Rights and Permissions website, at http://www.ucpressjournals.com/reprintinfo.asp. DOI: 10.1525/si.2007.30.3.347. 
their locations in social structures, and that interaction reinforces, but sometimes transforms, those structures. ${ }^{2}$ Hence, in the most general sense a social type is an attribute of social structures (Coser 1977:82-83).

Social types are useful constructs in assisting social researchers with making analyses of and normative judgments about the bases for social action, the configuration of acts and events that constitute it, and the consequences for it. Within the field of urban ethnographic research more specifically, it is often through the process of delineating various social types that urban ethnographers construct arguments about the kinds of people who presumably bring great harm to others in low-income urban communities (e.g., the gangbanger, the drug dealer) as well as those who may be the sponsors of positive social change, or at least of future promise (e.g., the community organizer, the against-all-odds achieving student).

The sociologist Elijah Anderson is one of the most well-regarded ethnographers for making use of social types in order to explicate the current situation and future possibilities of those who inhabit the impoverished urban core. One of the most vivid of such portrayals is his depiction of the "old head," or that mature or elderly African American male in a low-income community who was regarded as a figure of wisdom and authority many years ago. More specifically, Anderson defines the old head as follows:

\footnotetext{
Traditionally, the "old head" was a man of stable means who believed in hard work, family life, and the church. He was an aggressive agent of the wider society whose acknowledged role was to teach, support, encourage, and in effect socialize young men to meet their responsibilities regarding work, family, the law, and common decency.... Often the old head acted as surrogate father to those who needed attention, care, and moral support. (Anderson 1990:3)
}

By employing the concept of the old head, Anderson offers an alternative social type to that constituted in regard to many younger black men in the inner city. These younger men often stand as exemplars of that which has gone horribly wrong with social life in the urban sphere (e.g., fatherless families, escalations in crime, the proliferation of drugs in the community). Consequently, Anderson $(1990,1999)$ has argued quite consistently over the past two decades that the traditional old head has been replaced by a younger old head who, by virtue of garnering seemingly vast material reward through illicit activities, portrays an alternative image of success in American society. Accordingly, this younger individual exemplifies behaviors and attitudes that are in direct contrast to those of the traditional old head, who has achieved whatever he has by steady, long-term commitments to hard work in legitimate employment sectors.

Anderson's position on the dilemmas in the low-income African American community, especially as they concern the importance of social networks to the formation of shared moral codes in a community, has as one of its foundational tensions that absence of traditional old heads who are efficacious in engaging younger black men. For him, this absence is only the initial part of the problem. In its full and most severe form the problem is centered on these younger men's preoccupation with younger 
old heads, and their ultimate commitment to becoming such figures, rather than their commitment to following the advice and counsel of traditional old heads.

An extensive consideration of the views and attitudes of men who would fit into Anderson's category of old heads is offered in Mitch Duneier's Slim's Table: Race, Respectability, and Masculinity (1992) an ethnographic study of Chicago-based working-class African American men. In this work Duneier draws attention to working-class men as comprising a sector of the urban community that often gets ignored in contemporary discussion of urban communities steeped in conditions associated with chronic poverty and as affected by the disappearance of an African American middle-class presence. ${ }^{3}$ Hence, rather than invite further consideration of the so-called diminished presence of the African American middle class in lowincome, urban communities (and, by implication, the loss of traditional old heads of middle-class status), Duneier emphasizes how much certain working-class traditional old heads have not abandoned the inner city by virtue of their continued residence in or near poverty-stricken neighborhoods.

In looking so intensively at the situation and social outlook of mature, workingclass African American men, Duneier's work opened up a space for broadening the category of old head, at least along class dimensions. That is, Duneier demonstrated that men of more modest means, without access to a vast array of material resources, could also serve as old heads if there were mechanisms in place to link them more securely to younger African American men. The present article aims to further extend the parameters of the category of old head by exploring the views of two men who do not fit neatly into either the traditional or the new old head categories posited by Anderson and others. While sharing certain characteristics with the traditional type that Anderson presents, the kind of old head explored here also shares some of the characteristics of what Anderson defines as new old heads. More specifically, the kind of old head explored here is similar to the traditional old head in terms of his potential for reaching out to younger people in the hopes of providing some support or correctives for the behavior and dispositions maintained by those younger people. This old head also articulates an explicit, morally grounded perspective on how young people should address the issues circumscribing their lives (although, as I shall show, that moral foundation differs from that of the traditional old head).

However, like Anderson's notion of the younger old head, these old heads also have lived profligate lives as a youth or young adult. Accordingly, they stand less as counterexamples to the images of urban-centered black masculinity that are associated with delinquency, fatalism, or hostility than as men who have encountered and proliferated some of these images in their pasts. Accordingly, these old heads (whom I refer to as redeemed old heads) draw from both their earlier life experiences as "bad boys" and their more recent experiences as men who have survived turbulent pasts, in order to determine what kinds of approaches can-and, more important, cannot-work in reaching out to younger people. Their explanations of what can and cannot work, and why they feel as they do about such matters, 
elucidates how these men interpret that dimension of their selfhood that concerns being an old head and how they define a sense of social purpose in adopting that identity. Looking at these men's outlooks and opinions on the state of being for younger black men and the role that they try to play for those young men also brings to the surface an additional point of distinction between the redeemed and the traditional old head (the first being their different life course patterns). Those outlooks and opinions deliver an understanding of the difference in their moral codes that, as I shall show, affects how the redeemed old head defines his social purpose. ${ }^{4}$

\section{DEFINING THE REDEEMED OLD HEAD}

The redeemed old head refers to African American men who are past the age of forty and who have lived in or near poverty throughout much of their lives. They have experienced some of the same tribulations that confront today's young, lowincome black men: chronic unemployment, problematic relations with wives, girlfriends, and significant others, and involvements in criminal activity or incarceration. However, these men have survived their youth, meaning in the first case that they are alive and, thus, capable of representing their pasts as important points of consideration for younger males in low-income African American communities. A consideration of such men is especially important because the plethora of contemporary African American males caught in chronic joblessness, despair, and incarceration or other branches of the penal system will gradually move into the age category and status of old heads (i.e., to the extent to which they live long enough to become older men, given the turbulence of their earlier years).

The possibility remains that, either by choice or by circumstance, some of these individuals will become, or continue to be, intimately involved in the lives of younger relatives or other younger people in their communities. If so, they will find themselves in situations where their efforts to function effectively as role models and sponsors will mandate very different approaches than those offered by more traditional old heads. The differences have to do with the fact these more recent old heads have lived the kinds of lives that many younger people are living contemporarily. Accordingly, they will have more keen insight into the subjective aspects of that lifestyle. For those men in this group who will remain socioeconomically disadvantaged as they grow older, this also means that they must strive to be effective old heads either without access to the material and social resources acquired and maintained by traditional old heads. Thus, at least some of the redeemed old heads often have to draw upon more novel or less traditional techniques that differ from those employed by more traditional old heads in order to affect the lives of the younger people in their midst.

In defining the redeemed old head, it also must be taken into account that some of these men may be emotionally and physically scarred as a result of their economic disadvantage. They understand that some of their prior involvements as young men were not conducive for their own socioeconomic mobility and that their 
past experiences often continue to play a role in their efforts to secure a comfortable life for themselves. However, they have the personal knowledge that one can successfully navigate the urban context at least to the point of living to a mature age. Furthermore, they know that their experiences have taught them invaluable lessons about survival in impoverished urban communities. Hence, the messages that they offer to younger people, which is rooted in ideas about how to make sense of and survive that environment, reflects these men's own moral code and outlooks.

For some of those who are not familiar with the social dynamics of life in disadvantaged urban communities, the code adhered to by these old heads may seem contradictory in light of some of their behavior (e.g., when violence is both criticized by the redeemed old head as a pernicious factor in the community but also recognized as a necessary means of self-protection). Yet such contradiction works for these men, as it does for all people, as they deal with their life situations. Consequently, investigating their views provides a significant analytic moment for exploring the connection between understandings of self, social interaction, and social purpose. $^{5}$

\section{SYMBOLIC INTERACTION AS A TOOL FOR INVESTIGATING REDEEMED OLD HEADS}

The project of assessing the connection of self, social purpose, and social interaction as they pertain to redeemed old heads will involve the application of some features of symbolic interactionist theory, particularly those that concern how these men understand themselves and the particular limits and possibilities for functioning as old heads. Symbolic interactionists assert that rather than being an autonomous entity that fosters the production of social life, selfhood is a product of social interactions and social relations (Callero 2003). In fact, the predecessors of the symbolic interactionist tradition, including figures such as William James, George Herbert Mead, and Charles H. Cooley, laid the groundwork for such a conception of selfhood by directly implicating other people, or the social world more generally, in scholarly discussion of the constitution of the self (Meltzer, Petras, and Reynolds 1975). As Peter Callero (2003:121) has put it, symbolic interaction has traditionally concerned itself with the social production of the personal self, or how it is that people develop self-understandings, self-meanings, and self-concepts. More contemporary scholars have incorporated some of tenets of symbolic interaction to explore conceptions of one's public self, which is that dimension of self that is visible and known to others (Cahill 1998). My purpose here is to examine how redeemed old heads articulate their sense of self as old heads (which is, by definition, an explicitly public self), given the social experiences that they have encountered and the social context circumscribing their formal interview-based conversations with me.

Admittedly, this is a highly nuanced (and, some may believe, incomplete) incorporation of symbolic interactionism into social research. The nuance resides in the fact that this article does not draw from ethnography in its traditional form. There 
was no detailed collection of fieldnotes about how these redeemed old heads interacted with young people, nor how they did so with the adults who encouraged or asked them to function in that capacity. The only moments of genuine interaction brought into this analysis were those concerning the interaction of the researcher with the men prior to and during the interviews that produced the data utilized here. Otherwise, this article is based on the men's recollections and constructions of their interactions while growing up and with younger people.

A more thorough symbolic interactionist assessment of how redeemed old heads function must include formal ethnography such that analytic claims about precisely how meanings were construed in action can result. However, this article offers an initial step toward that end by achieving two objectives. The more basic one is the documentation of the precise kinds of meanings that were produced by the men about functioning as old heads. The more theoretically centered one is the implication of some tenets and theses of symbolic interactionism (including some ideas that were introduced prior to this tradition but that greatly informed it) in order to advance the project studying the subjective dimensions of selfhood, especially how connections are made by some men between their pasts and present experiences and their sense of self as old heads. Hence, it is best to regard this effort as a symbolic interactionist-informed commentary rather than as an authentic symbolic interactionist study. However, as an informed commentary it can offer a program for the latter, given its findings and arguments. Furthermore, by taking stock of how redeemed old heads regard themselves and their social utility for younger people firmly caught up in the grip of urban blight, this analysis will advance some understanding of the possibilities and limits for this form of social support in the impoverished urban arena.

The need to acknowledge the social possibilities for redeemed old heads should not be understated because even though, as Anderson argued, the traditional old head is not very much listened to by contemporary young men, the jury is still out on the kind of old heads discussed here because they have not yet emerged as a critical mass in the urban community. Indeed, as younger African American men who are socioeconomically marginalized and immersed in the criminal justice system move into more mature adult statuses later in life, the potential increases for significant numbers of redeemed old heads to proliferate in urban communities. $^{6}$

The pattern of this inquiry will be to look at how two such men explain their emergence into the status of old head, given their troubled pasts, and why they allowed me to document their explanations. We then turn to their accounts of how they moved from young men with troubled pasts to old heads today. In then focusing on the contemporary, I first take up how each defines the situation of contemporary youth, especially young black men, in comparison to their own youth. Then I move on to how these men explain their behaviors as mentors to younger people in their lives and how much they emphasize the limitations and shortcomings of mentoring as much as what they feel efficacious about doing. The article concludes with 
an overview of how each man articulates his vision of self as an old head, what this means for more formal symbolic interactionist research on the topic, and what it means for better understanding of how and why this kind of old head may best serve as a resource for young African American males in urban America.

\section{Encountering Two Redeemed Old Heads}

As previously stated, my field research with the two men who are the focus of this analysis involved extensive life historical interviewing. In my work with them I aimed to discover how each took account of his life experiences and how each understood himself to function as an elder figure in his own family and (at times) in his community more generally. In keeping with the point of emphasis of earlier work on the old head, my efforts centered on how these two men interpreted their interaction with younger males (although issues concerning females did emerge at various points in the conversations). Neither man has been a parent and, thus, neither had to regard the young people in their lives as their legal responsibility. Instead, both men determined to get involved in the younger people's lives (or, otherwise, readily accepted invitations by their relatives to get involved). Therefore, the course of my discussions with each man focused upon their life experiences with their nephews and some other younger males who were a part of their lives. It turned out that each was one of the few stable male adult figures in the lives of their nephews. Consequently, they were often turned to and relied upon quite consistently by other family members to address issues and concerns relevant to the young men in their families.

I initially encountered each man in the course of conducting fieldwork on the social outlooks of younger African American men (aged 20-30) in various urban communities. ${ }^{7}$ Both of these older men were socially connected to some of the younger men whom I studied. I would converse with these men about my research agenda, and they would share their views of what was going on with these younger men. One, whom I have given the pseudonym Smittie, still resides in the same low-income community in which he was reared (and where my research on younger African American men was centered). As he remains caught in the quagmire of disadvantage, he has fewer material resources to draw upon in order to act on the behalf of the young people in his life. As an older man in his mid-forties, he continues to grapple with economic disadvantage.

I would regularly converse with Smittie during moments in between fieldwork interviews for the younger men in my formal project. Smittie would share his views about these younger men and occasionally make comparisons between them and the men of his generation. These comparisons included references to gang-related activities, ideas about work opportunities, and relationships with women and children. I decided to conduct formal interviews with Smittie after he brought in some newspaper clippings of Reverend Dr. Martin Luther King Jr.'s visit to Chicago in the 1960s (a few years prior to his assassination). A much younger Smittie could be 
found in some of the pictures in these clippings. Smittie used this material to make some conversation about what it was like to be a young man on the west side of Chicago in the 1960s. It was clear to me that Smittie had a story that he wanted to tell and that our periodic conversations were not allowing for a more thorough telling of that story. ${ }^{8}$

The other man, whom I call Milton, has experienced considerable upward mobility in the past twenty years (he is now a pastor of a small church in the Midwest), although prior to that he was consistently on the margins of poverty and afflicted with numerous problems associated with life in lower-income communities. Hence, he represents the type of old head who has achieved the status of the more traditional old head, but only after living through some of the experiences encountered by Smittie. I first met Milton sometime prior to conducting my research on the younger men. As I knew him prior to the field research, he became a source of information early in my research agenda for younger black men. I would ask him about younger men in his life and use such information to inform my own work on the younger men.

Milton did not make overt requests to tell me his story, but instead would go into accounts of his past experiences and situations as a means of pointing out how much he was once like the men whom I was studying. Accordingly, he was more than willing to talk at length about anything that I asked of him. I was intrigued by him and offered him the chance to tell me his story in the same formal manner as Smittie (whom I actually finished interviewing some years prior to interviewing Milton). Hence, although each man came into the series of interviews with me under different circumstances, each came with the explicit intention of talking about being older men in (or close to) social environments largely composed of younger African American men in troubled conditions. Moreover, both were extremely interested in my research and curious about what I would ultimately find out about these younger black men.

I initially pursued each man in order to acquire a broader life-course perspective on the life experiences of African American men who were raised amid urban blight. However, each of their accounts informed me of the need to look more deeply at what I have come to label as redeemed old heads because each seemed to function as a bridge between the younger men whom I had been studying and the kind of old heads that the prior sociological research had explored. However, it was also the case that their compulsion to sit down with me conveyed that the interviews themselves were critical moments for them to construct images of themselves to me as well as deliver their vision of their social purpose as old heads. More specifically, the interviews were vivid opportunities to construct images of self and social purpose around the thematic of urban-based, young black men in trouble. Thus, herein lay a point of connection between their storytelling in the midst of my fieldwork of race, masculinity, and urban poverty and symbolic interactionism as an analytic tool for investigating some dimension of social experience. 
As the classic symbolic interactionist Herbert Blumer (1969:2) explained, three of the central tenets of symbolic interactionism are (1) that we know things by their meaning, (2) that meanings are created through social interaction, and (3) that meanings change though interaction. My interviews with Smittie and Milton were opportunities for each man to interact with me (albeit through the formalities of interview-style conversation) such that I could detect and then define their conceptualization of their selves as old heads. As I encountered these men in the later stages of my fieldwork with younger African American men, it was also the case that these images were formulated against a backdrop of younger African American men in a state of crisis. Thus, our conversations created a space for each man to consider and explain his own past as a particular story that stood separate from those produced by the younger men in my formal study.

Moreover, this meant that our conversations allowed the men to reflect upon their past interactions as the material by which they could construct accounts of their present-day selves. Symbolic interactionism provided critical tools for my effort to make sense of the experience of interviewing these men because the accounts of self produced through our conversations were in part constructed out of the social contexts circumscribing these conversations (i.e., my research on the problematic conditions concerning younger African American men) and in part produced by the men's drawing from their recollections of past interactions in order to formulate their accounts of self and social purpose as old heads. Thus, each man used the interviews as opportunities to engage what Callero (2003:119) describes as a core argument of symbolic interactionists: "The self is first and foremost a reflexive process of social interaction. The reflexive process refers to the uniquely human capacity to become an object to one's self, to be both subject and object. Reflexivity is not a biological given but rather emerges from the social experience."

Accordingly, rather than simply providing me with information about being older men somehow involved in the lives of younger people, these interviews are efforts for these men to deliver a coherent sense of themselves (or, in more formal sociological terminology, a sense of self) that situated them both as survivors of a turbulent and often vitriolic social world and as messengers for younger people who encounter that world and risk not being able to survive it. What makes this especially important for the redeemed old head is that these younger people are viewed by such men as being somewhat like the people these old heads recall being when they were young. Hence, a part of the means by which the redeemed old head makes sense of himself in the present is by reflecting upon his interaction with people who evoke images of himself in the past.

\section{From Bad Men to Old Heads}

The two men whom I explore as contrasting exemplars of the redeemed old head have similar life histories in that each was born and reared in low-income circumstances in the city of Chicago. Smittie was in his mid-forties when I first met him in 
the mid-1990s. He was born in New York City but raised in Chicago. As a young child he moved with his family into the Henry Horner Homes on Chicago's Near West Side community area. Smittie's own father was killed by a former wife (who was not Smittie's mother). Smittie grew up with mom and stepdad. He also had eight siblings in the family. The conditions of a crowded household were compounded by his stepfather's physical abuse of his mother, which persisted throughout Smittie's childhood.

In talking about what life in public housing was all about for him and his family, Smittie told me a story that took place near the time that the family first moved into the Horner Homes. He recalled waking up early one morning and seeing a strange man in the bedroom that he shared with some of his siblings. The man told him to remain quiet and go back to sleep so that the rest of the family would not be awakened. Smittie did as he was told, and he woke up later that morning to an aggrieved household because the television set and most of the other valuable household items were gone. That experience taught Smittie a lot about the kind of community that was now his home. Smittie grew up learning how to handle himself in this community quite well. He joined a local gang at an early age, and by his adolescence he had established a reputation in the community as someone who knew how to handle his business.

In fact, since his adolescent days in the 1960s, Smittie has been a gang member in a faction of the Vice Lord Nation, an associate of the Chicago chapter of the Black Panther Party and a participant in some of their community organizing efforts, a full-time employee for nearly a decade in domestic service at the Playboy Club of Chicago, and since the mid-1980s a chronically unemployed black man. The period of employment allowed him to curtail his gang activities throughout much of his twenties. Other than this experience, his life as a child, adolescent, young man, and now older man has been filled with a range of disappointments amid very few opportunities. Smittie has four nephews in his life, and he is close to each of them. At the time of our discussions he resided in his mother's house (his stepdad having passed away), which was within walking distance of the Horner Homes. One of his nephews resides there with him.

Although he has been a senior associate of a faction of the Vice Lords (more colloquially known as an "old gangster"), Smittie is connected to gangs mostly through his nephews. He explained, "I have three generations of gang fighters, gang members in my family now. And I spawned that. ... Right now my two nephews, or three nephews, four nephews and a cousin. Four of them are Mafia Vice Lords and the other one is an Undertaker Vice Lord."

In reflecting upon what it means to have a legacy of gang members emerge after him, Smittie said, "I'm so embarrassed by it though, I mean the kind of problems that they could bring to the family, you know. The grief and shit. I mean, that's a terrible sight seeing one of your people laying up there with a hole in his head or back or cold dead." 
Smittie's disappointment with how his nephews have followed him was countered by his realization that survival in their community was largely predicated on making such a choice. As he said:

They have to protect themselves in the community, you know. It's basically a protection thing. People will try to intimidate you. They will take from you. They will abuse you physically. So you know, if you live through it, then you have accomplished a lot. You survived it. But a lot of times they don't. They don't live through it, you know, because of the mentality of a lot of our youths today.

A consistent pattern in Smittie's expression was the seeming contradiction of being concerned about his nephews being in gangs and his comfort with the fact that they were immersed in the kind of protective network that a gang provides. Hence, rather than view his nephews as wayward youth, Smittie saw them as taking the necessary steps to survive in their social world. Smittie's own past activities in a gang allowed him to have this particular reading of the involvement of these young men. Their life experiences resembled his own. This allowed him to have an insider sensibility of their experiences, as well as to make it seem normal to those who may view such gang involvement as unusual and disturbing. I shall show how this mattered significantly in Smittie's reading of when and how to intervene on behalf of these men, and how to evaluate the choices that they made with their lives. Consequently, the image that he constructed of the youths in his life was not one of bad young men who he hoped could correct themselves as they matured but of young men who were doing what they had to in order to survive, and how he could serve as something of a resource for their survival instead of as an agent charged with facilitating their moral transformation.

Although I have known Milton since the early 1990s, I first interviewed him a little more than five years after meeting him. Milton is in the same age category as Smittie. He never knew his father, and throughout his life his mother worked as a domestic or in retail service capacities, including a bakery. He has eight brothers and sisters. Only one other than Milton has completed college. The rest have work histories ranging from steady blue-collar employment to chronic unemployment.

Milton grew up in various South Side Chicago neighborhoods until his teenage years when the family settled in the working-class community of Englewood. Although he reported being a solid student academically, Milton was better known as a standout high-school athlete in the early 1960s. He played both basketball and football and was actively recruited by various Division I programs in both sports. Milton explained that he was a far better basketball player and thus was much more sought after by colleges and universities in that sport. However, unlike more recent times when professional sport careers are contemplated by talented high school athletes, Milton knew of very few people who ever made it to the professional ranks from his background in the 1960s. Hence, his own thinking was vacant of that kind of consideration. Instead he embarked upon his quest for a new and exciting experience away from the blight of Chicago. 
Rather than attend college, a confused and curious Milton left high school before graduating and entered the military. His mother and high school basketball coach were very much against his decision. He said that he made this choice despite their objections because he wanted to leave home and venture into new and exciting places, and he believed that in the military he could do so at the expense of the federal government. As Milton explained, life at home in Chicago was a constant state of limited resources and diminished life chances. Hence, he placed as much value on the military's ability to take him away from those circumstances as on its promises to expose him to environments that he had never seen. Milton enlisted in the U.S. Marine Corps before completing high school. His plan was to earn his GED while in the military. It turned out that after his induction Milton surely did encounter a new and different geographic arena: he found himself in combat in Vietnam.

It was in Vietnam that Milton began his casual use of narcotics, beginning with marijuana. Over the next few years, extending beyond his discharge from the military after a tour of combat duty and some time in special services (his discharge from military service occurring without his receipt of a GED), he became addicted to heroin and a consumer of other narcotics as well. He remained so until the mid-1980s. Life during those years involved movement between Washington, D.C. and California, and a series of hustles, drug sales, and criminal activity; formal jobs; and informal employment prospects over the course of that time. In nearly two decades Milton figured to have made over a half million dollars selling narcotics. He had a few six-figure earnings years when he was heavily involved in distribution, and significantly less during other periods. He was a consistent user throughout that time and, thus, never accumulated anything in terms of financial savings from his activity. This and other illegal enterprises earned Milton a criminal record and a slew of short-term incarcerations throughout his early and mid-adulthood.

By the late 1980s Milton determined that he would have to change his life or he would face death on the streets of California. Choosing the former, he borrowed the car of a drug supplier whom he associated with and drove himself to a rehabilitation clinic. His successful rehabilitation was followed by completion of his GED and enrollment in a California community college. Thereafter, he enrolled and received a degree from a four-year higher educational institution. He completed some graduate study, and in the 1990s he entered into the ministry.

Milton has over two dozen nieces and nephews. Although he does not reside with any of them, he said that he is regarded by his extended family as a central figure for advice and counsel. This is especially for the children of his siblings who have experienced substance abuse problems or extreme economic hardship. While he maintains consistent contact with his nieces and nephews, he is invited into crises and special problems whenever they emerge. Such situations have included drug problems, arrests and detentions at police precincts, gang problems, and other matters. In explaining how he believes that he came to 
serve in this particular capacity in his family, despite the problems that beset him, Milton said:

I was always kind of looked at as the person I guess that had more sense than anybody or, you know, I was always sort of ahead of my time, you know, my uncle said I was always older than I really was. You know, and my mother treated me that way in that she taught me a lot, took me a lot of places she didn't take the rest of them. And so I think I particularly was always looked to, uh, for leadership in a sense, but also for wisdom, you know.

Milton argued that he boldly made his own choices in life, including the choice to pursue the military while not yet finished with high school and to ingest narcotics over a nearly twenty-year period. That mentality, together with his having survived near-death encounters in Vietnam and as a drug addict, provided Milton with a wide range of experiences from which to think about and apply in interacting with his nieces and nephews (and other young people who came into his life). It also allowed him the capacity to regard himself as highly efficacious in seeing out his goals and objectives in life (whether to acquire and ingest drugs or to abandon his reliance on illegal substances altogether). While not having overcome poverty, Smittie also saw himself as efficacious, at least to a certain extent, because he was a seniorlevel gang member who reached an age that many of his childhood associates had not, and Smittie had done so while continuing to reside in the same impoverished, violent-prone neighborhood where he was born.

The views that each man had of himself as efficacious were not all that mattered for how they were, quite literally, called into service as old heads. Each came into active service in this capacity because their relatives asked this of them. Milton said that his sisters would "make that phone call" over the years when problems emerged with his nephews. These calls actually began when Milton was still involved in narcotics use and other illicit activity (and, thus, may affirm that he was considered by his relatives to be something of a leader in the family). Milton explained that there were not many men around in the family to talk to the younger males. Filling that vacancy was a former athlete, war veteran, and (despite being addicted to drugs) hustler who continued to make ends meet when not reaping significant material return from such activity. Milton's ability to overcome his addiction further heightened his stature in the family and thus enhanced his capacity to be called upon as an old head by mothers (and sometimes fathers) who were struggling with Milton's nephews (and sometimes nieces).

Pure and simply, Smittie was the only male relative around for his nephews. Furthermore, he was a gang member who found his way to a job without ever losing his ability to navigate the streets. He explained that his mother and sisters regarded him as a crucial presence in the lives of their grandsons and sons, who were gang members and had not yet experienced legitimate work opportunities. In his own way, then, Smittie was also a model of hope for the women who asked him into service as an old head. The fact that both Milton and Smittie were available models of survival in social environments where men were either often not 
models or available illustrates how the social context matters for shaping the capacity for these men not only to emerge as old heads, but to embrace that status as well. Each man, as evident in their approaches to me to tell their stories, desired to claim a status validating their social utility, especially given the trauma of their pasts.

Herein lies the moment where a presymbolic interactionist theory speaks to the issues explored in this article. Although Mead (1934), as a critical forerunner of symbolic interactionism, stressed the importance of the relationship between reflexivity and the sedimentation of subjective experience, a more concrete concept in the Meadian vocabulary takes center stage here. This is emergence (which pertains to how Milton and Smittie emerged as old heads). For Mead, emergence is that which results from the interfacing of actors with environments. Each element, the actor and the environment, is a product of preexisting conditions. When the two are brought together, the emergence is an entirely different property than what existed prior to the convergence.

Thus, while it may make sense that Milton be called upon to serve as an old head because he achieved mainstream stability, Smittie is also called upon because in the context of his family and the social environment that they inhabit he resembles an image of information, hope, and possibility for helping the younger men to advance. Without the social backdrop of poverty and the invisibility of black men, Smittie may be regarded as little more than a down-on-his-luck older man. Yet, his value to others-or his emergence as a valued old head-is constituted out of the fact that no other resources are available to construe many other images of social support, at least those which could relate in meaningful ways to young men in his family. Consequently, his surviving as a gang member, his extreme street wisdom, and his sense of what kinds of mistakes young men can make and how to avoid them allow him to be registered as an old head. In looking at these cases, it is clear that emergence is part and parcel of the interaction process. ${ }^{9}$

As I shall soon show, Smittie and Milton provide evidence of how their past experiences play out quite literally in their approaches to interaction with their younger relatives. In fact, each man regards some of these relatives as selves that can potentially become much like the very selves that Smittie and Milton now believe themselves to be. However, both Smittie and Milton know that this process of becoming is not a given. More important, and despite the hopefulness of the women who have asked them to function as old heads, they also believe that they cannot affect change solely through their social intervention in the lives of these young people. Smittie and Milton believe this because, as I shall soon discuss, each takes very seriously that history matters. Each does so precisely because history involves the development of different ways of approaching and experiencing events, and both Smittie and Milton argue that how they handled their pasts (particularly how they made their choices to engage and then withdraw from delinquent activities) cannot be easily transferred to the young people in their lives. Their recollections of the past, however, can be a foundation upon which they take account of 
and construct their prospects for functioning as modern-day old heads. In order to grasp more fully how these men make sense of history, it is necessary to turn to their discussion of the distinct situation of contemporary African American youth. That discussion will set the foundation for investigating how each man considers his potential for being an influential force for younger people.

\section{The Situation of African American Youth}

Smittie and Milton felt strongly that the conditions affecting African American youth today are a lot more severe in comparison to the time of their youth. However, both said that there are significant differences between the reactions of contemporary youth in comparison with the past. Accordingly, both drew upon a standard discourse of young people lacking the respect and demeanor of youth of previous periods in time. For instance, both also pointed to increasing commitments to materialism as a descriptive feature of today's younger generation. They also said that the contemporary situation of urban despair, which they regarded as more critical than was the case during their own youth, also brought about a series of problems that were not on the horizon as much as they are now. As Smittie said:

It's a lot harder for the youth today because of the situations with drugs and the gangs and the peer pressure ... I'll give you an example. I just bought a pair of gym shoes from Payless that cost me fourteen bucks you know. And I passed by a group of young kids and they all had on like hundred and ten dollar gym shoes. And they says "Prolines, Prolines," that's what these [less expensive sneakers] are called, you know. It didn't bother me because I'm not caught up in material things. But kids, black youth of today are caught up in material things. And I think that is so silly. And the parents cater to that. And I think that's silly. You know, and I've actually seen them take gym shoes from kids, you know, jackets. It's a lot of peer pressure out there. (In my day) if you had a pair of Chuck Taylors [canvas rather than leather sneakers] you were happy. You know. PF Fliers. You had this stuff. You were happy to get it. And I think that's terrible. ... Now, the children of today if you tell them to go to Payless to get a pair of gym shoes they won't do it. They won't do it. And I think that's just peer pressure, you know. Because you got a pair of Nikes, I gotta get a pair of Nikes. No, uh uh. I don't think so.

For Smittie, however, crass materialism was not nearly the most problematic of circumstances concerning youth. That was surpassed by their predisposition to engage in violence. As he explained:

A fourteen-year-old kid killed a very close friend of mine last week. Just rode up to him on a moped and shot him in the head. And we buried him Saturday. Also Saturday one of my cousins - he was playing on the railroad tracks. He couldn't play on the streets because of the drug dealers and the gang members. And so they go on the tracks and they throw rocks and stuff. And he was killed by a train, him and his buddy.... We as a society, we as a people, should come to a conclusion and put a stop to this nonsense, you know, because our babies are dying. You know, this generation is committing genocide. 
In arguing the root causes of these and other social problems in the community, Smittie said:

Money. Drugs. Uh, drugs. Definitely drugs has a lot to do with it. Just like any other enterprise or business, you want to expand it. And when you expand it you're going to run into peaks and valleys, and how do you solve that? You either climb it or go under it. And a lot of times they just go through it.... Not only with the drugs, but I mean a fourteen-year-old walk up to a, drive up to a burly fortyyear-old man and shoot him in the back of the head? C'mon, that's ridiculous.

It is important to consider Smittie's comments in the context of his own past experiences as a gang member. For Smittie, it was not the mere existence of gangs but the more retrograde activities of more recent generations of gang members that were the sources of the contemporary problem. To be clear, it was not the existence of gangs per se that Smittie identified as the problem. After all, Smittie is regarded as a senior figure by his gang (again, a faction of the Vice Lords, one of the major gang factions in the city of Chicago). The concern, therefore, had more to do with the absence of formal opportunities for employment and thus the availability of more free time for frivolous gang activities that could bring harm or sanction to gang members. In Smittie's mind this was the root cause of the wanton violence that he believes that modern gangs promote. Recall that Smittie himself did withdraw from extensive participation once he landed his job at the Chicago Playboy Club. Thus, he believed that with an increased opportunity structure young men would not have to become so deeply embedded in neighborhood gangs and the exacerbating aggression and violence that were their attributes. As he said in discussing the current state of affairs with gangs:

You meet up with these different individuals just because you know you wear your hat that way, ${ }^{10}$ he says, "Aw, you're a punk. I'll just shoot you." And I've seen that done numbers of times. ... There's some guys so crazy now with the different organizations out here. They just kill each other just for any, I mean anything. Just name it and they'll do it. . . And a lot of these young brothers don't have the opportunities to grow because they're so caught up with that peer pressure. And they'll never grow out of it because like I say once you get trapped into the organizations, it's just a matter of time before you're either dead, or you kill somebody or somebody kills you. You know, I mean it's just that obvious.

In Smittie's earlier days gang membership consisted of participating in illicit activities, but also in group activities that mandated that one learn to manage money, take responsibility, and exercise certain forms of control in public space through community organizing and other grass-roots initiatives that were common in the late 1960s. Of course, one could say that the very same skills are cultivated in modernday gangs, given their rising role in narcotics sales and other income-generating activities (Levitt and Venkatesh 2000; Venkatesh and Levitt 2000; Venkatesh 2000). However, in Smittie's view, gangs have moved far beyond those objectives and thus are destructive in ways that they previously were not. ${ }^{11}$ 
More important, however, Smittie's claims here provide insight into the kind of moral code that he adheres to, which starkly contrasts with that which Anderson argues is promoted by traditional old heads. The stark contrast is that, for Smittie, the gang presence is not the problem. In his mind, rather than being inherently problematic, gangs are logical and acceptable products of his social world, which is riddled with diminished resources and opportunities. Smittie believes that extreme socio-economic disadvantage is what leads to gangs fostering social problems because gangs have responded to these conditions by encouraging behaviors and actions that greatly intensify violence and personal threat. Thus, Smittie does not call for the elimination of gangs, primarily because he regards them as special resources in an otherwise resource-depleted environment. Instead, he desires that gang members show more caution and forethought so that they may live as long as he has been able to.

Smittie's perspective on this matter-and the alternative moral code implicit in it - is made even more evident by his telling of the following story, which conveys how he addressed one situation of the so-called problem with today's urban youth in a uniquely different form than what would be expected from the traditional old head. He said:

\begin{abstract}
I was working at this hotel about six months ago. And I used to work from eleven at night to seven in the morning. So one night about ten-thirty I was waiting on the Madison Street bus at Madison and Albany, minding my own business. But always have a seven-inch knife in my pocket, for these particular situations. And, you know, like I said, group of young kids came by ranging from the age of about 10 to about 15, but it was about seven or eight of 'em, right? And one of them asked me, "What was I riding?"- - meaning what gang was I in. I told him the Madison bus to work, to take care of my family. I told him, "The Madison bus (is what I am riding)." He said, "You are a smart M-F, you know?" And I said, "Look brother, please, get you some business. I'm on my way to work." One of them picked up a 40-ounce beer bottle and hit me in my head with it. Now, by that time I done pulled my knife out and I grabbed him. He was ten years old. And I threw this kid on the ground and I was fitting to stab him. And I looked at him, and I said, "It would be a waste of my life if I hit this kid in his head with this knife." And he was, "Please mister, don't kill me. Please don't kill me." And meanwhile his buddies had ran off and found sticks and stuff. And I actually ran from these kids so I wouldn't hurt them. Or I wouldn't get hurt. ... That's all it was, you know. I mean, they travel in packs and they're not afraid to move out. They're not afraid to move on you, believe me.
\end{abstract}

Smittie had no reservations about possibly getting violent with these youths. As a young man who once stood in their position, he was quite familiar with the situation that confronted him. Thus, while his actions might appear to be extreme, given what others might have done while faced with a similar situation, Smittie's interpretation of the youth in that moment was quite consistent with what many others might have thought - a group of profligate youth in the inner city who were looking for trouble. However, Smittie's statement about his reaction to them was not in line with traditional old head reaction. He was poised to stab one of the young men and did not 
regard such action as excessive. Furthermore, Smittie walks through the streets of his community armed with a knife (and, on occasion, a gun) because he generally professes to having no qualms about defending himself as aggressively as necessary, despite the youthfulness of any such provocateur. Hence Smittie can say only that he is unlike some of the young men in his neighborhood not because he would behave differently with respect to violence but only because he identifies the futility or risks involved in certain potentially violent encounters. His willingness to handle himself in the same ways that some young people do indicates how well connected he is to the social worlds of these younger people. This personal logic is critical for how he determined how to interact (and in some cases, intervene) in the affairs of his nephews. It allows him to develop an acute sense of how to approach young people (both in the literal as well as the figurative sense, as made evident in Smittie's story of his literal approach to these youths) and what limits and possibilities exist when he is trying to make these approaches.

In less dramatic ways, Milton made his case about the situation of youth by first saying that their socioeconomic life chances were more threatened than those of his generation:

I think for young people it's harder to get a job than it was when I was young. Many of the jobs or similar jobs that I worked at or most of us worked at when we're young, I see older people working at those jobs now. Like in the fast food places and things like that, when I was coming up those were nothing but kids that worked those jobs.

This was but one aspect of the difficult condition that Milton thought was bearing upon younger people. He had some sense of what the transformations in the urban economy meant for the availability of jobs. Also, like Smittie, he went on to discuss issues such as crime, gangs, and consumption interests as making for different experiences for young people in comparison to his own youth. Unlike Smittie, however, Milton spent considerable time talking about how much more access to information young people now have and what that meant for the differences across generations. He began his commentary by talking about the role played by advances in technology (i.e., the availability of computers, television) as a critical factor in the development of more knowledgeable, inquisitive, and opinionated-but not necessarily wiser-youth. As he put it:

Well I guess the biggest thing that strikes me is that they're much smarter, you know, they're much more smarter...than my generation, but they have the same difficulty when it comes to trying to figure what to do with all this information, you know, they, I mean they're not so much wiser. They're just smarter. They know more, you know.... I mean the conversations you have with them now and the conversations that I had with them, I would have never had with my uncle, you know, at that age. I mean, they're smarter. You know, they're more inquisitive and it don't take them long to have opinions about things.

When asked to explain his sense of how the differences between his generation and the present one came about, Milton said: 
I mean, just the television, the computers ... they exposed to it. You know, they have all these different avenues of receiving knowledge, you know, that we didn't have... That accounts for them being smarter... . You just can't expect them to put a harness on it and say just because I'm a certain age and this is an adult and I'm just supposed to stifle myself, you know.... And I think that's been a difficult thing for a lot of parents, you know, and people raising children, you know, to accept this fact that "Hey, this person can think. They got information and they got ideas..." Like I say, they're not all that wise, you know, but they have the information, you know, and right or wrong, whether you agree with how they see it or perceive it, or want to use it, you know, the fact is you gotta respect the fact that it's there.

Milton went on to explain that young people use their access to these materials to advance their own interest in "get(ting) all you can while you can." The similarity in Milton's and Smittie's claims about the different social environment confronting modern-day young people is that both spoke in ways that affirmed their own decency as individuals. ${ }^{12}$ Smittie was decent because he was not the same kind of gang member as were the young men of today. Alternatively, Milton was decent because he was not the crass consumer that many younger people appear to him to be.

The discussions of young people also provided a basis for understanding how the men generally accounted for their capacity to serve as resources for younger people. In particular, the discussion exemplified the limits that each man recognized in his ability to connect with younger people. In the case of Milton, having explained himself as moved beyond an earlier phase of preoccupation with consumption and the good life, he more recently began to regard himself as a man of strong religious convictions intent upon providing outreach and service to others. In framing today's youth as extreme materialists, he conveyed that there were spaces whereby he would disconnect with these youths despite any success at connecting with them. Smittie argued that younger people were often beyond his reach because they were too immersed in the fast and furious lifestyle associated with the current-day gang culture of extreme violence and intense immersion into high income-generating illegal activities. The men's emphasis on the challenges of connecting with youth becomes more evident in the next section's discussion of how these men perceive themselves as engaging the role of old head.

\section{Self-Assessments of Old Heads in Action}

Having made clear that each man established some grounds for understanding why and how they might encounter limitations in connecting with the younger people in the social worlds, I can now turn to how each explained and discussed his functioning as a mentor. For men who have lived lifestyles much like contemporary profligate youth, managing one's interaction with them took forms that severely contrast with those presumed to be associated with traditional old heads. After reading the accounts presented in the previous section, one might feel that Smittie and Milton were close to abandoning the idea that each can serve effectively on the 
behalf of younger people. To be clear, this is not the case. Rather, their sense of limitations and boundaries has allowed them to more carefully determine when and how they can provide such service. Smittie's interaction with one of his nephews articulates how this is so. Here he discusses how he responded to this young man's eagerness to react violently to someone who the nephew believed was withholding money from him:

I had to actually drove him down on the ground physically. He had a gun. He was gonna shoot somebody over ten dollars. This was Sunday, yesterday. And I'm trying to tell him, you know, you're reacting, you're not thinking. You know, and I took the gun, you know. He actually buckled up at me. He wanted to fight, and I'm looking at him and I'm saying I see myself in him, you know. He's reacting and not thinking, you know. Over ten dollars. So what did I do? I took the gun from him. Gave him ten dollars and kicked him out. Told him I don't want to talk to him any more. And then he came back, later on about nine or ten o'clock, "I'm sorry, I won't do that no more." I told him, "You know, you don't react. You think first. There's a lot of goddamn humps in the ground out there in Burr Oak (cemetery) from people reacting and not thinking." You know, and I try to, I try to, I try to express that to him. You know, because I can't stop them. I can't. I mean, they've grown. I can only tell them what not to do. I'm saying, I don't want to see them in these positions (of getting into trouble due to their behavior). But if they got to be there, if you gotta be there, you gotta be smart. You can't be stuck on stupid looking for dumb. Straight up you have to be smart. That's as simple as that.

Smittie's comments reveal that his effort here was geared not toward making an explicit moral claim about shooting someone but to establishing that his nephew's determination to do so would introduce a series of problems for that young man. The alternative moral code surfaces here in Smittie's commentary that at no point does he pass judgment on his nephew for wanting to resolve his anger by getting violent, but that his nephew does not reflect upon the range of problematic outcomes for such action.

Although the specific content of the situation was different, Milton also demonstrated that intimate connection to some of the experiences encountered by innercity youth mattered for his style of engaging them. Recall that Milton also was a substance abuser in his past. He has a nephew who is following his own early life pattern of drug abuse and drug selling. He said that he actually introduced this nephew into the world of drug selling during his own years of involvement. Although this nephew is aware that Milton no longer leads that kind of life, there have been no illusions on Milton's part that he can change the behavior of this nephew. As Milton explained:

You know, because basically what he's going through now is the same road I went through, you know, in terms of being out there in those streets, you know, on your own. And basically just looking to get high.... You know, it's like when, uh, people ask me to talk to him, I says, "Well, what am I going to tell him?" You know, he knows. I think somehow, you know, we tend to think people who are in trouble like, you know, don't know and it's something that he could tell you more about... The last long conversation I had with him, you 
know, I was really shaking my head. I mean he could tell me more (than I could tell him) about the consequences, the problems, what he needs to do with his life, but right now he's just making choices.

Milton's understanding of what he can-and more important cannot-do on behalf of this nephew is made clear by his following remarks:

I mean, he just can't wake up tomorrow and say I'm not gonna do this anymore. I mean, there has to be a process. But I mean right now, he's choosing not to ... not to deal with that ... not to go through a process. So, I don't think there's a lot I can do but just continue (to talk to him).... Since he already knows, you know, I can't tell him nothing about the life he's in, he knows.... I can only show him model behavior. Just, you know, let him see it. And hopefully, again, it'll just give him information that'll help him make a better decision one day. You know, maybe, maybe not.

Again, some guiding themes in Milton's comment are that he is sure that he cannot immediately initiate the kind of change that he desires for his nephew. Consequently, he accepts that he can only serve as a model of proper conduct and a source of information about the choices that his nephew and other young people around him have to consider.

In a manner similar to Milton's, Smittie stressed that he could present choices but not direct others' actions. Even when he aggressively intervened in a matter, he knew that his action could provide the kind of resolution that he wanted only for the short term. Hence, his management of the situation was predicated upon a clear understanding that his ability to control the behavior of the other party was limited.

The following remarks, which Smittie made at another point in our conversations, seemingly advance the idea that he has given up on serving as a mentor. However, what he says out of frustration with the challenges of trying to mentor younger people actually turns into an expression of his personal philosophy of mentoring, which is in concert with what was just argued about him. He said:

I don't try to talk to them any more. I'm burned out with that man, I mean I've been told (by young people) to mind my own business, "Get me some business, let me deal with my life," you know. You try to make the road smoother for them. But you can lead a horse to water but you can't make them drink, you know. I tell them, "Look, if you walk to the left, you can walk on clouds. If you walk to the right, you gonna walk in the shit. Walk to the right, you can walk in the shit." They gonna walk in the shit before they walk in the clouds. Simple as that. So I don't try to tell them anymore. ... I'm not the one 'cause I don't have the patience anymore, you know. The way they disrespect their parents these days, they're headed for, like I said, penitentiary or the graveyard. I just can't, I can't relate to them like I used to. I don't have that type of patience anymore. You have to be really patient with the kids of today. They just disrespect their parents so much that I think it's the parents' job now. It's not a friend or a neighbor that can tell them anything that they want to hear.

Despite his remarks here, Smittie has not given up on talking to some younger people. In fact, even in the midst of this comment he conveyed what he says to 
younger people, all the while remaining frustrated with them. In looking at what he does say to them, the same theme of limitation and boundaries emerges. He makes the point that all he (or anyone in his position) can do is deliver information. The ways in which that information is handled, however, is beyond his control.

Milton, who was a little less disturbed by the challenge of connecting with youth (and, perhaps not unimportantly, more equipped with economic and status resources to do so as he is a college graduate and now an ordained minister), also described precisely how he tries to interact with youth. Being in a position to have experienced positive change after a long bout with poverty and other problems (this is where his current socioeconomic status becomes important), Milton was not particularly disturbed that change might be hard to produce with young people. In talking about his approach to them, he said:

I share my experiences with them. And I guess my thing about kids, young people, is that, you know, the most we can do as adults is just sort of give them the information and let them know what's going on. Whether it's by way of telling them about our lives ... well, I guess that's the only way to do it ... so that they at some point will have a stash of options, you know, and they can at least know, you know, what they're choosing when they do become smart enough to make choices, you know, and stuff. I don't preach any particular philosophy to them, but I do model on things. ... I just try to, you know, model that as a way hoping that they will see that.... Or at some point if they don't go that way, but they're caught in a situation where they can reach out and make a choice then they'll know what they're choosing.

In a follow-up on that point, Milton said:

I think (my relatives) hold me as sort of a, you know, in awe in a certain respect, but I mean, these kids are very strong-minded now, and, you know, we can talk and we can tell them, but like I said, I don't know how much I could tell them if they don't already know.... And I'm not sure just because I'm saying it, you know, it ... it might give it some validity, you know, even if they've heard it before, but just to have an instant change 'em, I don't know, I think that's all based on an individual. You know, it's hard to tell.... So I think, yeah, if they ask me to talk to 'em, I think they expect me, but I don't think they have great expectations of the results.

In similar fashion to Smittie, Milton said that it is impossible to determine what the outcome of advising will be. As he put it, "You know, it's difficult to know. I would assume that it's just they take out things and just store it, you know, it just becomes part of other information that they get, you know, and at some point they dissect it themselves and figure out how to use it, you know."

In essence, although each man had much to say about how he tried to intervene in the lives of younger relatives, each of the comments also clearly referenced how the men thought they were limited in the effect that they could produce. In what may seem like a sad irony, both men's sense of limitation is a product of their of intimate connection to and involvement in similar circumstances concerning troubled youth. Thus, the subjective dimension of being a redeemed old head involves something much more complex than a portrayal of such men as individuals who have 
engaged certain behaviors in their past and who are now older and interested in being helpful to the young people. It also involves a particular understanding of when and how to connect with these youth, especially those who experience the more pernicious aspect of urban, low-income life. Sometimes that connection involves the willingness to engage youth in behaviors that are potentially threatening to the old head's own life. At other times it involves knowing what may and may not work, and having the presence of mind to know that it may take considerable time before that advice sets in. In coming to these realizations, the newly emerging old head also promotes a sense of public self that is finely grounded in-and, thus, a product of-his readings of his past and present interactions.

\section{CONCLUSION-MAKING SENSE OF SELF AS A OLD HEAD}

Symbolic interactionism is a theory of experience as much as it is a theory of social structure (Denzin 1992:2). As such, proponents of this school of thought assert that notions of the self are generated through the rhetoric and storytelling that people produce about, and for, themselves (Denzin 1987). Hence, rhetoric and storytelling constitute efforts to deliver accounts of how certain kinds of selves have emerged from social experience. First, Smittie and Milton presented images of self that reflected their "survivor" status as products of low-income, urban, African American communities that engaged the profligate and often self-destructive behaviors pursued by many men who reside in such environments. Their efforts to distinguish between the younger African American men of today who inhabit disadvantaged urban communities and themselves was, in part, a project of demonstrating their decency as public selves. They did so by presenting themselves as less committed to crass consumerism and less willing to pursue actions that brought about immediate gratification while risking the impact of extreme sanctions. In short, these two men presented themselves as wiser, more careful, and more considerate of the outcomes of social options and prospects than were contemporary younger people.

However, in judging younger people, especially those in their lives to whom they strove to provide counsel and advice, Smittie and Milton were also less judgmental than would be individuals who adhered to what can be regarded as a more mainstream moral code about behavior. These men did not remain fixed on the immorality of illegal or violent activity but, instead, saw such pursuits as understandable options for people in deprived communities to pursue. They also saw such people, if not as well aware of the outcomes for their choices, then as individuals who would make such choices according to their own standards and measures for behavior. Thus, these young people were viewed as having a degree of agency that mere counseling would not necessarily deter. The redeemed old head, then, took account of the choices that he made in his own past as a guideline for understanding what could or could not be done to deter the actions of today's younger people.

What this means is that the redeemed old head may not call for the kind of morally grounded response from younger people that Anderson considers to be 
the calling of the more traditional old head. Instead, Smittie and Milton call for the recognition that such young people ultimately will make their own choices and that while the intervention of the old head can mitigate in the presence of certain crises (as Smittie tried to do when his nephew planned to shoot someone), the redeemed old head is careful about not identifying himself as a principal source of any such transformation. In pointing out how much young people themselves must be the source of their own transformation, Smittie and Milton affirm their own redemptive actions as critical for their ability to survive their pasts. Hence, their conversations about what they can and cannot do for the benefit of their younger relatives is a testimonial about what they did for themselves as young people, and perhaps a strong self-acknowledgment that they were extremely agentic in situations where others-such as the multitude of African American men who succumbed to drugs, violence, and fatalism of various sorts-were not necessarily so.

Smittie and Milton have come to understand themselves as old heads because they were called into service as such by others who saw these two men as capable of delivering services and ideas to certain young people that were beyond the capacities of those calling upon the men. In telling their stories, both men explained themselves as having been prepared to function in this way as a result of the particular configuration of their past life experiences. Both men validated themselves as survivors of urban malaise who essentially took it upon themselves to make certain choices that ensured their survival. Their validation of self-initiative was also evident in how much they spoke of their limited capacities to change the behaviors of other people (especially those for whom they were asked to serve as mentors or role models). Hence, their self-image as old heads is grounded in recollections of the tribulations of involving themselves in the lives of younger people and their sense of what they experienced throughout the course of their own lives.

The image of old head that they have constructed, then, is an artifact of reflecting upon their prior interactions and experiences, and building a functional sense of self from them. Their image of self as old heads is not steeped in the notion that old heads transmit value systems to profligate or troubled youth but founded in the belief that they provide either information and insight about choice making so that younger people can take stock of the options available to them (as per the behavior of Smittie) or register themselves in the minds of younger people such that, upon those younger people committing to changing their behavior, the old head can be a source of support, counsel, and advice (as per Milton's behavior).

This constitutes a very different notion of self than what is implied in the work of Anderson. In arguing about the traditional old head, Anderson (1999:71) said that such a figure's functioning centered on the transmission of values concerning hard work and other explicit characteristics. He also argued that today such old heads have lost most of their esteemed social status (pp. 72, 272). This article aimed to demonstrate that the redeemed old head calls for a slightly different conception of who old heads are and how they function. Men like Smittie and Milton assert that 
being old and out of the so-called fast life does not have to mean a complete loss of status because both of these men were listened to (at least to a certain extent) and, as far as they believe, are respected by younger people. That respect and deference does not always mean a change in behavior by younger people, but it may be the case that because he has led the kind of life that he has, and experienced changes along the way, the redeemed old head is positioned to know and understand quite intimately why this is the case.

It remains for other analyses to explore and comment upon how the mechanisms of interaction and communication unfold for redeemed old heads (and this is where the more traditional research method associated with symbolic interactionism can offer much insight). Other analyses should also explore how such old heads might be able to become a better or more effective resource in blighted urban communities. One crucial step to take in such work, and one that is implied by the case of Smittie, is how to encourage better functioning for such old heads when they continue to live without significant material resources that might enhance their service as mentors and role models. As the capacity for more redeemed old heads to emerge comes into being, this situation will explode onto the policy landscape, and theoretically informed thinking on the front end might help produce better situations in the future, both for redeemed old heads and the people they aim to serve.

Acknowledgments: For reactions and commentary on earlier drafts of this article the author wishes to thank Reuben May, Carla O'Connor, David Smilde, Sandra Smith, the anonymous reviewers, and audiences at the 2005 Society for the Study of Symbolic Interaction Couch-Stone Symposium at the University of Colorado, Boulder, and the University of Georgia Workshop on Culture and Institutions and Race and Social Processes Colloquium Series.

\section{NOTES}

1. Simmel's contribution to understanding the term came less from his actual efforts to define it and more from his efforts to characterize and interpret the social relevance of various social types. The term was introduced by the political scientist Geatano Mosca to refer to a social grouping that shares a combination of social forces and culture such that it can engender its own political structure (Martindale 1981). However, Mosca's purposes were far from the present article's concern.

2. This discussion of the social type parallels Sheldon Stryker's discussion of the relationship of social interaction, the self, and social structure. As he stated, social interaction produces the resources for constructing the self (role identities), which, in turn, guides and patterns behavior that defines social structure (Stryker 1980). Hence, while largely Simmelian in origin, the concept of social type is useful for symbolic interactionist configurations of social process.

3. The debate about the extent to which members of the African American middle class have distanced themselves geographically from the lower-income sectors of the black American community has raged since the 1980s (see Massey and Denton 1993 and Wilson 1978, 1987, 1996 for opposing perspectives on the matter). However, public response to this debate, irrespective of the sides taken, has not erased scholarly attention to the issue of whether younger African American men are making best use of older, economically secure men for counsel and support 
(in addition to Anderson and Duneier see Billson 1996; Blake and Darling 1994; Bowman 1995; Gordon, Gordon, and Nembhard 1994; Herbert 1994; Hunter and Davis 1994; Majors and Gordon 1994; and Mincy 1994).

4. It is important to make clear that in introducing this version of the old head, the objective of this inquiry is not to refute the claims made by Anderson and Duneier about the existence and potential relevance of traditional old heads for being of service to low-income, urban communities. Instead, the present concern is to broaden the category such that older African American men who do not fit into the traditional or new old head depictions are given appropriate analytic space.

5. Discussions of moral codes for African American men in urban communities immediately raise attention to the argument made by Anderson $(1990,1999)$ concerning the code of the streets. He argues that such a code is a pervasive cultural system of behaviors and dispositions propagated throughout impoverished urban neighborhoods (Anderson 1999). That system allows some members of these communities to display and enact power, influence, and intimidation in public space (largely because, as Anderson argues, such power and influence is not a prominent part of their lives, given their marginalization from work opportunities and other dimensions of mainstream America). The system also provides such people with the means to navigate the urban arena (including effectively interacting with or averting those who aim to intimidate or dominate others in such a space). Indeed, there is some considerable connection between my reference to moral codes for various kinds of old heads and the so-called code of the streets. After all, each focuses to some extent on aggressive, hostile, or threatening behaviors in public settings - and the manners by which people negotiate everyday life around them. However, I refer more to value judgments and assessments of behavior in my use of the term moral codes, while Anderson remains preoccupied with behavioral patterns and the knowledge of when to employ them or how to avoid being affected by them.

6. The literature referenced in the third note makes clear how severe the social conditions are for black men in the age group 15-35. Additional studies, including Mauer 1999 on criminal justice and Bowman 1993 and Moss and Tilly 2001 on labor market and employment problems, also demonstrate the crises afflicting men in this age group, who, if they live long enough and overcome some of their tribulations, will be prime candidates for redeemed old head status.

7. This endeavor has resulted in a book, The Minds of Marginalized Black Men: Making Sense of Mobility, Opportunity, and Future Life Chances (Young 2004) and a series of continuing research endeavors on how young, low-income African American men from urban communities think about future work prospects, desired qualities of life, and other aspects of future-oriented thinking.

8. In part, I suspected that Smittie felt that what he could tell me had at least as much value as whatever the younger men were saying to me in my formal study. Furthermore, the younger men were paid $\$ 25$ for completing a three-part interview with me. As an unemployed man with no steady source of income at that point in his life, it was clear to me that it was more than a small joke whenever Smittie would mention that men like him should be able to tell their stories and get "a little something" like the younger men were. I certainly grew intrigued by Smittie, and I felt obliged to let him share in the rewards of an interview. This eventually became a series of five interviews over the course of a few months. As an acknowledgment of his age and life situation, I eventually paid him three times what the younger men made for telling me their stories.

9. Although Mead discussed the concept of emergence throughout his main corpus of work, it is not as systematic or explicit as his discussion of many of the constructs and ideas that he is most well known for contributing to symbolic interactionist and pragmatist theory. Johannes Han-Yin Chang (2004) offers a comprehensive critical assessment of Mead's theory of emergence.

10. The tilting of a hat toward the left or right side of one's body is an indication of a particular gang affiliation. 
11. Although Smittie was resolute in his views on this matter, it is worth noting that in a study of the social history of Robert Taylor Homes, a public housing project in Chicago's highly regarded South Side African American community, Sudhir Alladi Venkatesh (2000) discusses the community advancement initiatives that gangs in that area pursued. Venkatesh makes the point that as one of the few durable social organizational entities, area gangs were appealed to by residents to organize constructive initiatives despite whatever else they did that many would regard as destructive to community growth.

12. Anderson (1999) introduces the critical distinctions made in African American urban communities between decent and street people. Anderson proposed that these distinctions are more analytical than empirical, meaning that people can be viewed as occupying either status depending on their economic and social circumstances, or some other measure of how they are evaluated by others. Much like everyday people, though, Anderson himself, applies each term pretty consistently to the same people while describing them in the course of his research. For the present purposes, the ways in which redeemed old heads regard themselves can be considered as efforts to claim decency in a social milieu composed of people who often have little recourse for presenting themselves to others as such. It should not be surprising that these efforts surface at a point in the life course of these men where they have significantly less time than would younger people to reconstitute a positive public self and hence willingly embark upon the project of doing so.

\section{REFERENCES}

Anderson, Elijah. 1990. Streetwise: Race, Class, and Change in an Urban Community. Chicago: University of Chicago Press.

-1999. Code of the Streets. New York: Norton.

Billson, Janet Mancini. 1996. Pathways to Manhood: Young Black Males' Struggle for Identity. New Brunswick, NJ: Transaction.

Blake, Wayne M. and Carol A. Darling. 1994. "The Dilemmas of the African American Male." Journal of Black Studies 24 (June):402-15.

Blumer, Herbert. 1969. Symbolic Interactionism. Englewood Cliffs, NJ: Prentice-Hall.

Bowman, Philip. 1993. "The Impact of Economic Marginality on African American Husbands and Fathers." Pp. 120-37 in Family Ethnicity, edited by H. P. McAdoo. Newbury Park, CA: Sage. . 1995. "Marginalization of Black Men and the Underclass Debate." Pp. 309-21 in The Decline in Marriage among African Americans. New York: Sage.

Cahill, Spencer E. 1998. “Toward a Sociology of the Person.” Sociological Theory 16:131-48.

Callero, Peter L. 2003. "The Sociology of the Self." Annual Review of Sociology 29:115-23.

Chang, Johannes Han-Yin. 2004. "Mead's Theory of Emergence as a Framework for Multilevel Sociological Inquiry." Symbolic Interaction 27(3):405-27.

Coser, Lewis. 1977. Masters of Sociological Thought: Ideas in Historical and Social Context. New York: Harcourt, Brace, Jovanovich.

Denzin, Norman K. 1987. The Recovering Alcoholic. Newbury Park, CA: Sage. .1992. Symbolic Interaction and Cultural Studies. Oxford: Blackwell.

Duneier, Mitchell. 1992. Slim's Table: Race, Respectability, and Masculinity. Chicago: University of Chicago Press.

Gordon, Edmund T., Edmund W. Gordon, and Jessica Gordon Nembhard. 1994. "Social Science Literature concerning African American Men." Journal of Negro Education 63(4):508-31.

Herbert, Bob. 1994. "Who Will Help the Black Man: A Symposium." New York Times Sunday Magazine, November 20.

Hunter, Andrea G. and James Earl Davis. 1994. "Hidden Voices of Black Men: The Meaning, Structure, and Complexity of Black Manhood." Journal of Black Studies 25 (September):20-40.

Levitt, Steven D. and Sudhir Alladi Venkatesh. 2000. "An Economic Analysis of a Drug-Selling Gang's Finances." Quarterly Journal of Economics 115(3):755-89. 
Majors, Richard G. and Jacob U. Gordon, eds. 1994. The American Black Male: His Present Status and Future. Chicago: Nelson-Hall.

Martindale, Don. 1981. The Nature and Types of Sociological Theory. Prospect Heights, IL: Waveland.

Massey, Douglas and Nancy Denton. 1993. American Apartheid: Segregation and the Making of the Underclass. Cambridge, MA: Harvard University Press.

Mauer, Marc. 1999. The Race to Incarcerate. New York: New Press.

Mead, George Herbert. 1934. Mind, Self, and Society. Chicago: University of Chicago Press.

Mincy, Ronald B. 1994. Nurturing Black Males. Washington, DC: Urban Institute Press.

Meltzer, Bernard N., John W. Petras, and Larry T. Reynolds. 1975. Symbolic Interactionism: Genesis, Varieties, and Criticism. Boston: Routledge and Kegan Paul.

Moss, Philip and Christopher Tilly. 2001. Stories Employers Tell: Race, Skill, and Hiring in America. New York: Russell Sage Foundation.

Simmel, Georg. 1971. On Individuality and Social Forms. Chicago: University of Chicago Press.

Stryker, Sheldon. 1980. Symbolic Interactionism: A Social Structural Version. Menlo Park, CA: Benjamin/Cummings.

Venkatesh, Sudhir Alladi. 2000. American Project: The Rise and Fall of a Modern Ghetto. Cambridge, MA: Harvard University Press.

Venkatesh, Sudhir Alladi and Steven D. Levitt. 2000. “'Are We a Family or a Business?' History and Disjuncture in the Urban American Street Gang." Theory \& Society 29(4):427.

Wilson, William Julius. 1978. The Declining Significance of Race: Blacks and Changing American Institutions. Chicago: University of Chicago Press. . 1987. The Truly Disadvantaged: The Inner City, the Underclass, and Public Policy. Chicago: University of Chicago Press. 1996. When Work Disappears. New York: Knopf.

Young, Alford A., Jr. 2004. The Minds of Marginalized Black Men: Making Sense of Mobility, Opportunity, and Future Life Chances. Princeton, NJ: Princeton University Press. 